\title{
Bioformulation of Xenorhabdus stockiae PB09 for controlling mushroom mite, Luciaphorus perniciosus Rack
}

\author{
Piyarat Namsena ${ }^{1}$, Prapassorn Bussaman ${ }^{1 *}$ and Paweena Rattanasena ${ }^{2}$
}

\begin{abstract}
Background: Bioformulations are the preparations that contain beneficial microorganisms as active ingredients and they may represent a novel alternative to be used in crop protection because of their safety to humans and nontarget organisms. Xenorhabdus sp. is an entomopathogenic bacterium that symbiotically associates with nematodes of the family Steinernematidae and has potential to be used in bioformulations due to its pesticide activities. The aim of this study was to determine the efficacy of bioformulations containing Xenorhabdus stockiae PB09 for controlling mushroom mites.

Results: The results showed that different Xenorhabdus bioformulations, including wettable powder (WP), liquid cell pellet (LC), and liquid supernatant (LS) were shown to cause very high miticidal activities at $90.25,86.50$, and $92.78 \%$, respectively. When $X$. stockiae PB09 bioformulations were stored at room temperature $\left(28 \pm 2^{\circ} \mathrm{C}\right)$ and $4{ }^{\circ} \mathrm{C}$ for up to 60 days, their viable cells and efficacy were found to decrease. However, storing at $4{ }^{\circ} \mathrm{C}$ could relatively maintain both viable cells and efficacy of the bioformulations, especially after 45 days of storage, whereby all the formulations that were kept at $4{ }^{\circ} \mathrm{C}$ had $5-10 \%$ and $2-15$ times higher miticidal activities and viable cells than that kept at room temperature, respectively. Storing at $4{ }^{\circ} \mathrm{C}$ was more appropriate than room temperature for maintaining both viable cells and miticidal activities of all $X$. stockiae PB09 bioformulations.
\end{abstract}

Conclusions: In conclusion, this study showed that WP and LC formulations were found to be effective and have potentials to be further developed as commercial products for controlling mushroom mites.

Keywords: Bioformulation, Bacteria formulation, Biopesticide, Xenorhabdus stockiae, Mushroom mite

\section{Background}

Bioformulations are the biopesticides formulated with active ingredients based on safe microorganisms such as bacteria, viruses, fungi, nematodes, or plant extracts and semiochemicals (Gašić and Tanović 2013). Nowadays, increasing interests in using bioformulations may be due to an escalation of the people's awareness of healthy food and organic agriculture. Also, the use of synthetic chemicals has been restricted due to the occurrence of pathogen resistance and the prolonged contaminations in the

\footnotetext{
*Correspondence: prapassorn.c@msu.ac.th

${ }^{1}$ Department of Biotechnology, Biocontrol Research Unit, Faculty of Technology, Mahasarakham University, Maha Sarakham 44150, Thailand

Full list of author information is available at the end of the article
}

environments (Diehl and Fehrmann 1999). Therefore, several trials have applied the bioformulations for solving these problems and resulted in effective protections in many crop plants (Elad et al. 1996). In addition, the microorganism-based bioformulation, either in the form of individual application or part of the integrated pest management (IPM), may represent an alternative strategy for crop protection because of their safety to humans and non-target organisms (Gašić and Tanović 2013). A number of bioformulation products commonly use Bacillus thuringiensis, especially for insect control. Also, there are a variety of user-friendly forms of bioformulation products, including dusts (DP), granules (GR), wettable powders (WP), oil dispersions (OD), and liquid formulations (Knowles 2005). The WP formulation of B. licheniformis 
(N1E) mixed with corn starch and olive oil was evaluated against tomato gray mold caused by Botrytis cinerea in both artificial and natural infection settings, and the results showed that spraying of WP formulation mixed with a 100 -fold diluted N1E was found to be the most effective approach (Lee et al. 2006). Furthermore, B. thuringiensis Berliner (B.t.) mixed with water-soluble granular formulation was evaluated against the rice leaffolder, Cnaphalocrocis medinalis Guenee, and the results showed that the first spraying of the formulation containing $2.5 \mathrm{~kg} / \mathrm{ha}$ B.t. led to the lowest leaffolder damage at only $8.21 \%$ after 7 days and also the highest grain yield at $28.58 \mathrm{~kg} / \mathrm{plot}$ (Kandibane et al. 2010). Currently, several entomopathogenic bacteria have received much attention as biological control agents. Xenorhabdus spp. are gram-negative bacteria belonging to the family Enterobacteriaceae and symbiotically associate with entomopathogenic nematodes of the family Steinernematidae (Boemare et al. 1993; Forst et al. 1997). A complex cooperation between these bacteria and their nematodes leads to severe toxicity to many insect species (Akhurst 1983; Herbert and Goodrich-Blair 2007; Herbert Tran et al. 2009). When the nematodes infest their insect hosts, they release the symbiotic bacteria from their intestinal tracts into the insect host's hemocoel, and this action usually results in the death of insect hosts within $48 \mathrm{~h}$, most likely due to the combined actions of bacterial multiplication, septicemia, and secretion of toxins (Bowen and Ensign 1998; Sicard et al. 2004; Yang et al. 2012). Cell suspensions and cell-free supernatants of Xenorhabdus spp. have been shown to be highly effective under laboratory conditions for controlling of several insect pests, such as Plutella xylostella L. (Abdel-Razek 2003; Mahar et al. 2008), Hopila philanthus (Fuessly) (Ansari et al. 2003), Frankliniella occidentalis (Pergande), Thrips tabaci (Lindeman) (Gerritsen et al. 2005), Galleria mellonella L. (Mahar et al. 2005), Spodoptera exgua (Hubner), Otiorhynchus sulcatus (Fabricius), Schistocerca gregaria (Forskal) (Mahar et al. 2008), and Tribolium castaneum (Herbst) (Shresth and Kim 2010). Moreover, Bussaman et al. (2009) reported that application with Xenorhabdus nematophila and Photorhabdus luminescens caused the highest mortality of Luciaphorus perniciosus Rack, a mushroom mite, at 85 and $83 \%$, respectively. The cell suspension of $X$. nematophila that was cultivated for $48 \mathrm{~h}$ at the concentration of $1 \times 10^{8}$ cells $/ \mathrm{ml}$ was found to cause the maximum mortality of L. perniciosus (85$88 \%$ and reduction of fecundity of its offspring $(22.84 \%)$. Moreover, the different parts of X. stokiae isolate PB09 culture (whole cell suspension, cell-free supernatant and crude cell extract) were also evaluated and the results showed that cell-free supernatant of X. stokiae PB09 was the most effective to control mushroom mite, resulting in miticidal activities at $89 \%$ (Bussaman et al. 2012).
Nonetheless, the efficacy of Xenorhabdus spp. bacteria in the form of bioformulations has yet been explored. This is important to understand the suitable bioformulation forms of Xenorhabdus spp. before proceeding to the field experiments (Suprapta 2012). Therefore, in this study, $X$. stockiae PB09 in various bioformulation forms were evaluated for controlling mushroom mites.

\section{Methods}

Bacteria, mushroom, and mite cultures

Xenorhabdus stockiae PB09 was isolated from Steinnernema siamkayai, its symbiotic nematode, that was originally obtained from the Department of Agriculture, Ministry Agriculture and Cooperatives, by using the methods previously described by Kaya and Stock (1997). Xenorhabdus stockiae PB09 was initially isolated using the nutrient bromothymol blue triphenyltetrazolium chloride agar (NBTA) medium (containing $3 \mathrm{~g} / \mathrm{L}$ beef extract (Criterion, USA), $5 \mathrm{~g} / \mathrm{L}$ peptone (Criterion, USA), $8 \mathrm{~g} / \mathrm{L} \mathrm{NaCl}$ (Ajax Finechem, Germany), $15 \mathrm{~g} / \mathrm{L}$ agar (BDH, England), $0.04 \mathrm{~g} / \mathrm{L}$ Triphenyltetrazolium chloride (TTC) (Sigma Chemical, USA), and $0.025 \mathrm{~g} / \mathrm{L}$ bromothymol blue (BTB) (Labchem, England)) and incubated in the dark at $28{ }^{\circ} \mathrm{C}$ for $24 \mathrm{~h}$. The colonies that developed blue pigment were characterized as phase I which were picked up and grown in 250-ml flasks containing $100 \mathrm{ml}$ Luria-Bertani (LB) broth (containing $10 \mathrm{~g} / \mathrm{L}$ tryptone (Merck, Germany), $5 \mathrm{~g} / \mathrm{L}$ yeast extract (Criterion, USA), and $10 \mathrm{~g} / \mathrm{L} \mathrm{NaCl}$ (Ajax Finechem, Germany)) at $200 \mathrm{rpm}$ and $28{ }^{\circ} \mathrm{C}$ in the dark overnight and finally used as seed culture (Lacey 1997). To prepare the bioformulations, $X$. stockiae PB09 seed culture $(10 \mathrm{ml})$ were inoculated into LB broth $(1000 \mathrm{ml})$ and placed in an incubator shaker at $200 \mathrm{rpm}$ (New Brunswick Scientific, USA) and $28{ }^{\circ} \mathrm{C}$ for $48 \mathrm{~h}$ in the dark to obtain the bacteria at the concentration of approximately $10^{10}$ cells/ $\mathrm{ml}$ which was used in the next step for producing the bioformulations as described in Table 1 . The mycelia of Lentinus squarrosulus mushroom, obtained from the Mushroom Researchers and Growers Society of Thailand, was sub-cultured using $90-\mathrm{mm}$ plastic Petri dish plates containing potato dextrose agar (PDA) (Himedia, India) and incubated at $25^{\circ} \mathrm{C}$ in the dark. The mushroom mycelia was then inoculated into a sawdust and sorghum grain mixture to generate the fresh spawn (Bussaman et al. 2006). Mushroom mites (L. perniciosus) were collected from infested $L$. squarrosulus basidiocarps and composts obtained from Rapeephan mushroom farm in Khon Kaen province in the northeast of Thailand. A pair of male and female mites was placed in each glass bottle containing $L$. squarrosulus spawn and maintained at $28{ }^{\circ} \mathrm{C}$ for in-house breeding for all experiments (Bussaman et al. 2012). 
Table 1 Ingredients of $X$. stockiae PB09 bioformulations

\begin{tabular}{lll}
\hline Formulations & Ingredients & \\
\hline Wettable powder (WP) & Bacterial suspension & $1000 \mathrm{ml}$ \\
& Corn starch (Super-Find, Thailand) & $400 \mathrm{~g}$ \\
& Olive oil (Bertolli, Italy) & $50 \mathrm{ml}$ \\
& Sucrose (Mitrphol, Thailand) & $50 \mathrm{~g}$ \\
Liquid supernatant (LS) & Supernatant & $1000 \mathrm{ml}$ \\
& Corn starch (Super-Find, Thailand) & $50 \mathrm{~g}$ \\
& Tween 20 (Pubchem, USA) & $8 \mathrm{ml}$ \\
& Ethanol (BDH Prolabo, France) & $5 \mathrm{ml}$ \\
& Cell pellet & $1000 \mathrm{ml}$ \\
& Corn starch (Super-Find, Thailand) & $50 \mathrm{~g}$ \\
& Tween 20 (Pubchem, USA) & $8 \mathrm{ml}$ \\
& Ethanol (BDH Prolabo, France) & $5 \mathrm{ml}$ \\
\hline
\end{tabular}

\section{Bioformulations of X. stockiae PB09}

Xenorhabdus stockiae PB09 culture in LB broth at the concentration of approximately $10^{10} \mathrm{cells} / \mathrm{ml}$ was thoroughly mixed with the materials described in Table 1 to generate the different bioformulations. For the WP formulation, the mixture was completely dried at $40-45{ }^{\circ} \mathrm{C}$ in a drying oven (Memmert $\mathrm{GmbH}$, Germany) for $18-24 \mathrm{~h}$ and subsequently ground using a blender (Philips, Thailand) to form powder. The grinding process was carried out intermittently to minimize heat generation. The powder was then sieved through a 200-mesh filter (Retsch, Germary) to produce the WP formulation. To generate the liquid formulations, bacterial culture was centrifuged at $10,000 \mathrm{rpm}$ and $4{ }^{\circ} \mathrm{C}$ for 15 min to separate the bacteria cells from the supernatant. The bacterial pellet was re-suspended in an equal volume of saline $(0.85 \%$ $\mathrm{NaCl}$ (Ajax Finechem, Germany)) and then mixed with the ingredients indicated in Table 1 to generate the liquid cell pellet (LC) formulation. The culture supernatant was filtered through a $0.22-\mu \mathrm{m}$ filter (Ventical chromatography, Thailand) and mixed with the indicated ingredients to produce the liquid supernatant (LS) formulation. Then, all formulations were stored at $4{ }^{\circ} \mathrm{C}$ until required (Lee et al. 2006).

\section{Effects of $X$. stockiae PB09 bioformulations on miticidal activities}

One hundred adult L. perniciosus female mites (1 day old) were transferred to each of 50-mm Petri dish plates that containing mushroom mycelia grown on PDA medium. A total of $500 \mu \mathrm{l}$ of each $X$. stockiae PB09 bioformulation (Table 1$)$ at the concentration of $1 \%(w / v$ or $v / v)$ was then sprayed onto the L. squarrosulus mycelia infested with mushroom mites using mini-sprayer. The same volumes of LB broth and $0.04 \%(w / v)$ propargite (Omite 20, Thailand) were used as negative and positive control groups, respectively. All plates were covered with lids and placed in a growth chamber (Memmert $\mathrm{GmbH}$, Germany) at $28{ }^{\circ} \mathrm{C}$ and $80 \%$ relative humidity in complete darkness. The experiments were performed in four replicates for three times. Miticidal activities were monitored every $24 \mathrm{~h}$ for 5 consecutive days after the treatments using the microscope (Nikon, Japan). Miticidal activities rate was calculated by the formula below:

$$
\text { Miticidal activities }=\left(\frac{A-B}{A}\right) \times 100
$$

where $A=$ surviving female mites in negative control treatment; $B=$ surviving female mites in $X$. stockiae PB09 bioformulation treatment.

\section{Effects of storage time and conditions on X. stockiae PB09 bioformulations}

$X$. stockiae PB09 bioformulations were stored at room temperature $\left(28 \pm 2{ }^{\circ} \mathrm{C}\right)$ and $4{ }^{\circ} \mathrm{C}$ for $0,15,30,45$, and 60 days and evaluated for the bacterial cell viability and the ability to induce miticidal activities. One gram (WP formulation) or $1 \mathrm{ml}$ (LC and LS formulations) of each formulation was suspended in $100 \mathrm{ml}$ of sterile distilled water and examined for cell viability and miticidal activities by the methods described above.

\section{Statistical analyses}

All data were subjected to analysis of variance using the general linear models procedure (SAS Institute, Cary, $\mathrm{NC}$ ). Data on the percentages of miticidal activities were arcsine transformed before analysis. Significant differences between the treatments were determined using the LSD test at $p<0.05$.

\section{Results and discussion}

\section{Effects of X. stockiae PB09 bioformulations on miticidal} activities

The different bioformulations of $X$. stockiae PB09 were found to induce mortality of $L$. perniciosus at different levels (Table 2). For all the bacterial formulations (WP, LC, and LS), the percentages of miticidal activities increased with time in all treatments and became steady 3 days after application. Three days after the treatments, the LS formulation of $X$. stockiae PB09 was extremely virulent and induced very high percentage of miticidal activities (92.78 $\pm 3.85 \%$ ), followed by WP and LC formulations (90.25 \pm 3.33 and $86.50 \pm 13.47$, respectively), and, strikingly, all of which were not significantly different from $0.04 \%(w / v)$ propargite $(100 \%)$. After the treatments with all the formulations, the percentages of miticidal activities on day 3 were 1.2 -fold to 1.4 -fold higher than that on day 1 . In addition, no dead mites were observed after application with LB broth. 
Table 2 Percentages of miticidal activities after treatments with X. stockiae PB09 bioformulations

\begin{tabular}{|c|c|c|c|c|c|}
\hline \multirow[t]{2}{*}{ Bioformulation } & \multicolumn{5}{|c|}{ Miticidal activities (\%) } \\
\hline & Day 1 & Day 2 & Day 3 & Day 4 & Day 5 \\
\hline WP & $64.10 \pm 3.41^{c B}$ & $87.76 \pm 2.35^{\mathrm{bA}}$ & $90.25 \pm 3.33^{\mathrm{aA}}$ & $90.25 \pm 3.33^{\mathrm{aA}}$ & $90.25 \pm 3.33^{\mathrm{aA}}$ \\
\hline LC & $69.58 \pm 2.47^{\mathrm{bB}}$ & $85.83 \pm 4.85^{\mathrm{bAB}}$ & $86.50 \pm 13.47^{\mathrm{aA}}$ & $86.50 \pm 13.47^{\mathrm{aA}}$ & $86.50 \pm 13.47^{\mathrm{aA}}$ \\
\hline LS & $72.58 \pm 2.67^{b c}$ & $88.16 \pm 2.36^{\mathrm{bB}}$ & $92.78 \pm 3.85^{\mathrm{aA}}$ & $92.78 \pm 3.85^{\mathrm{aA}}$ & $92.78 \pm 3.85^{\mathrm{aA}}$ \\
\hline Propargite & $100.00 \pm 0.00^{\mathrm{aA}}$ & $100.00 \pm 0.00^{\mathrm{aA}}$ & $100.00 \pm 0.00^{\mathrm{aA}}$ & $100.00 \pm 0.00^{\mathrm{aA}}$ & $100.00 \pm 0.00^{\mathrm{aA}}$ \\
\hline LB broth & $0.00 \pm 0.00^{\mathrm{dA}}$ & $0.00 \pm 0.00^{c A}$ & $0.00 \pm 0.00^{\mathrm{bA}}$ & $0.00 \pm 0.00^{\mathrm{bA}}$ & $0.00 \pm 0.00^{\mathrm{bA}}$ \\
\hline
\end{tabular}

Means within the same column followed by the same lower case letters are not significantly different $(p<0.05)$ as compared by LSD test. Means within the same row followed by the same upper case letters are not significantly different $(p<0.05)$ as compared by LSD test

$W P$ wettable powder formulation, $L C$ liquid cell pellet formulation, $L S$ liquid supernatant formulation

Among the three formulations, LS formulation of $X$. stockiae PB09 caused the highest miticidal activities $(92.78 \%)$ which may be due to that miticidal compounds were mainly in the bacterial supernatant. This was similar to the previous report of Bussaman et al. (2012) which showed that cell-free supernatant of $X$. stokiae culture led to both the highest miticidal activity $(89.00 \%)$ and the lowest mite fecundity (41.33 eggs/ gravid female), when compared to its whole cell suspension and crude cell extract. The cell-free supernatant of $X$. nematophila was also found to be highly virulent to the insect pests, including S. exgua, P. xylostella, O. sulcatus, and S. gregaria, within 48 h (Mahar et al. 2008), and also be extremely toxic to G. mellonella (95\% mortality) when being applied at the concentration of $4 \times 10^{7}$ cells/ $\mathrm{ml}$ (Mahar et al. 2005). This may suggest that cell-free supernatant of Xenorhabdus spp. could be suitable to be developed into the bioformulations. Some of the secondary metabolites produced by Xenorhabdus spp. that were highly active against destructive insect pests have been identified, including toxin complexes (Tc) (Ffrenchconstant et al. 2007), hydrolytic enzymes, e.g., chitinase protease, lipase and phospholipase (Forst et al. 1997), and antibiotics, e.g., xenorhabdins, xenorxides, and xenocoumacins (Bode 2009), which directly affected the immune and hormonal systems of the insects (Owuama 2001).

\section{Effects of storage conditions on bacterial cell viability and ability to cause miticidal activities of X. stockiae PB09 formulations}

Effects of storage conditions on bacterial cell viability of $X$. stockiae PB09 formulations

The number of viable $X$. stockiae PB09 cells in all bioformulations were found to decrease with time. The results indicated that a number of viable $X$. stockiae PB09 cells in WP formulation were gradually decreased and the storage at $4{ }^{\circ} \mathrm{C}$ did not help to maintain the viable cells during the first 30 days of the storage, but the benefits of $4{ }^{\circ} \mathrm{C}$ was gradually shown during 45-60 days of storage (Fig. 1). The $4{ }^{\circ} \mathrm{C}$ storage could maintain the bacterial viable counts in WP formulation from $2.68 \times 10^{8}$ to $9.66 \times 10^{5}$ cells $/ \mathrm{ml}$, but the room-temperature storage could maintain from $2.68 \times 10^{8}$ to only $4.51 \times 10^{5}$ cells/ $\mathrm{ml}$. Interestingly, $4{ }^{\circ} \mathrm{C}$ storage was found to be very beneficial for the LC formulation as it could help to keep the very high number of bacterial viable cells during 60 days of storage, resulting in remaining $7.75 \times 10^{7}$ cells $/ \mathrm{ml}$ (from $2.68 \times 10^{8}$ cells $/ \mathrm{ml}$ ), whereas the room-temperature storage could maintain the remaining viable cells at $5.50 \times 10^{6} \mathrm{cells} / \mathrm{ml}$ (from $2.68 \times 10^{8}$ cells $/ \mathrm{ml}$ ) (Fig. 2 ) Therefore, the $4{ }^{\circ} \mathrm{C}$ is more appropriate for storing both WP and LC formulations than the room temperature. The LC formulation was found to have higher cell viability than the WP formulation may be because of that the protocol to produce LC formulation had no desiccation step. Also, LC formulation contained Tween 20 as chemical amendment that could hold a high level of water to protect the viable cells from the effects of adverse environments, for example, desiccation, osmotic pressure, and temperature stress during the re-suspension and the experiments (Fillinger et al. 2001).

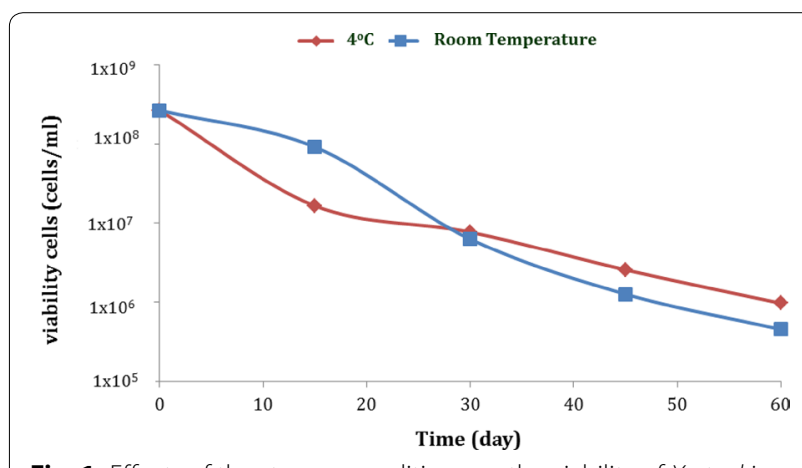

Fig. 1 Effects of the storage conditions on the viability of $X$. stockiae PB09 cells in WP formulation 


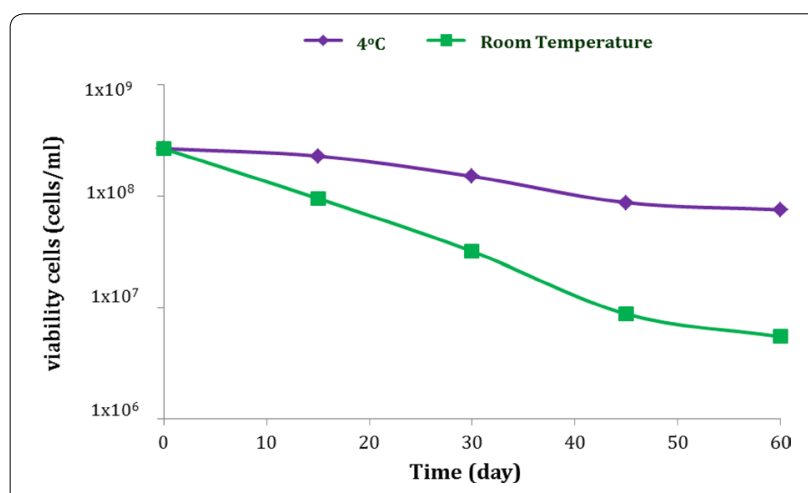

Fig. 2 Effects of the storage conditions on the viability of X. stockiae PB09 cells in LC formulation

\section{Effects of the storage conditions on miticidal activities of $X$. stockiae PB09 formulations}

The miticidal activities of $X$. stockiae PB09 formulations gradually dropped during the 60 days of storage at $4{ }^{\circ} \mathrm{C}$ and room temperature (Fig. 3). The maintenance conditions at $4{ }^{\circ} \mathrm{C}$ for 60 days resulted in WP, LC, and LS formulations having miticidal activities at 68.08-90.25, 65.44-86.51, and 62.08-92.78\%, respectively. The WP and LC formulations caused the levels of miticidal activities significantly higher that of LS formulation. Miticidal activities of all three formulations had 1.3-fold to 1.5-fold decrease during the $4{ }^{\circ} \mathrm{C}$ storage, and LS formulation showed the maximum reduction of miticidal activity.

Xenorhabdus stockiae PB09 bioformulations that were kept at room temperature were shown to have lower of miticidal activities when compared to those stored at
$4{ }^{\circ} \mathrm{C}$. The WP, LC and LS formulations stored at room temperature for 60 days could cause the miticidal activities at 59.37-90.25, 61.83-86.51 and 52.16-92.78\%, respectively. The WP and LC formulations stored for 60 days induced similar levels of miticidal activities, which were significantly higher than LS formulation. Miticidal activities of all three formulations had 1.0-fold to 1.8 -fold decrease during the room temperature storage, and LS formulation showed the maximum decrease of miticidal activity (Fig. 3). From these results, $4{ }^{\circ} \mathrm{C}$ was more appropriate than room temperature for maintaining the miticidal activities of all X. stockiae PB09 bioformulations.

Although LS formulation had the highest miticidal activity, this formula was not suitable for long-term storage. The results suggested that WP and LC formulations are more likely to be stable than LS formulation for long-term storage in both $4{ }^{\circ} \mathrm{C}$ and room temperature. This may be because the metabolites in cell-free supernatant of the LS formulation had low stability and could not tolerate the adverse environmental conditions, whereas the WP and LC formulations were more stable and could maintain miticidal activities better than LS formulation because of their components (corn starch and olive oil) that contributed to the attachment and longevity of the bioactive compounds (Fravel et al. 1998). In the formulation, starch could become gelatinized and form a cross-linked structure in which the biological control agent could be trapped (Fravel et al. 1998), and this also may enhance the attachment of the bacteria to the mushroom mycelia (Burges and Jones 1998). In addition,

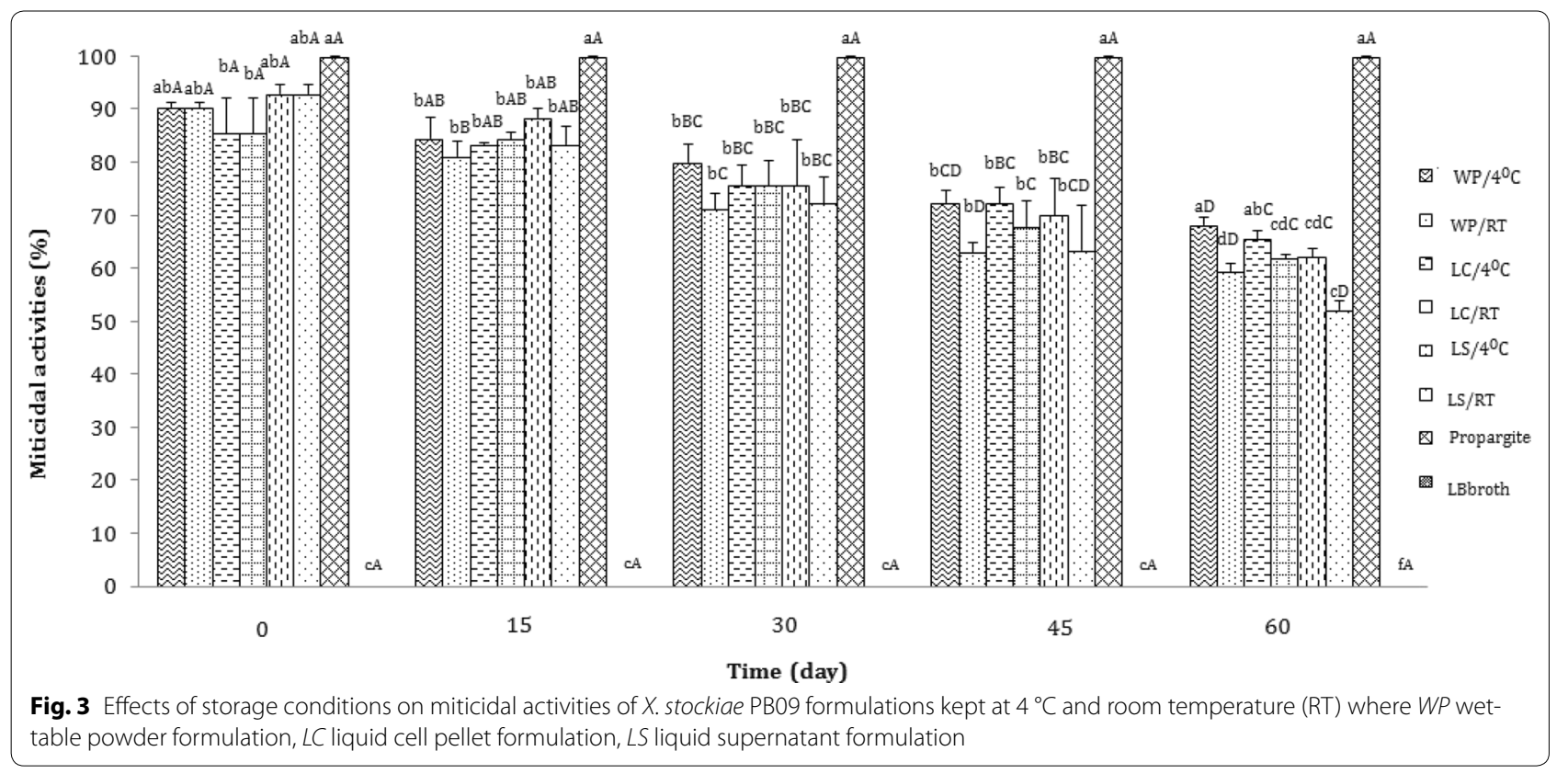


olive oil and sugar may serve as food for viable bacteria and also regulate the water availability in both WP and LC formulations (Lee et al. 2006). The use of attachment agents has been shown to be beneficial in many formulations (Knowles 2005). For example, the WP formulation of $B$. licheniformis could effectively control the tomato gray mold caused by $B$. cinerea under production conditions and in plastic-house artificial infection experiments (Lee et al. 2006). The talc-based WP formulation of Pseudomonas fluorescens TDK1 + Pf1 strains (amended with or without chitin) was shown to cause high levels of leafminer's larval mortality at approximately 65-85\%. This formulation was effective at reducing the incidences of leafminer and collar rot in groundnut under laboratory settings as well as greenhouse and field conditions (Senthilraja et al. 2010). Similarly, the talc and wood powder formulations of Bacillus spp. and P. fluorescens significantly decreased the root rot disease index percentages when compared with the control $(p>0.05)$ (Sallam et al. 2013). For these reasons, the WP form may have the most promising potentials for future development of $X$. stockiae PB09 formulations due to long storage stability, good miscibility with water, and convenient application using conventional spraying equipment (Brar et al. 2006; Knowles 2005).

\section{Conclusion}

In conclusion, this study showed that the WP and LC formulations were found to be effective for controlling mushroom mites. Also, WP may be the most appropriate formulation for the future development of $X$. stockiae PB09 as biological control agent for controlling mushroom mites and, perhaps, other insect pests.

\section{Authors' contributions}

PB designed the research project, supervised the experiments and prepared the manuscript. PN designed the experiments, performed the experiments and prepared the manuscript. PR edited and proofread the manuscript. All authors read and approved the final manuscript.

\section{Author details \\ ${ }^{1}$ Department of Biotechnology, Biocontrol Research Unit, Faculty of Technol- ogy, Mahasarakham University, Maha Sarakham 44150, Thailand. ${ }^{2}$ Community Public Health Sub-Department, Department of Applied Sciences, Faculty of Science and Technology, Rajabhat Phranakhon Si Ayutthaya University, Ayutthaya 13000, Thailand.}

\section{Acknowledgements}

This study was financially supported by Mahasarakham University. Thanks to the Department of Biotechnology, Faculty of Technology for providing laboratory equipments and facilities.

\section{Competing interests}

The authors declare that they have no competing interests.

Received: 29 December 2015 Accepted: 28 March 2016

Published online: 12 April 2016

\section{References}

Abdel-Razek AS (2003) Pathogenic effects of Xenorhabdus nematophilus and Photorhabdus luminescens (Enterobacteriaceae) against pupae of the Diamondback Moth, Plutella xylostella (L.). J Pest Sci 76(4):108-111

Akhurst RJ (1983) Neoaplectana species: specificity of association with bacteria of the genus Xenorhabdus. Exp Parasitol 55:258-263

Ansari MA, Tirry L, Moens M (2003) Entomopathogenic nematodes and their symbiotic bacteria for the biological control of Hoplia philanthus (Coleoptera: Scarabaeidae). Biol Control 28(1):111-117

Bode HB (2009) Entomopathogenic bacteria as a source of secondary metabolites. Curr Opin Chem Biol 13(2):224-230

Boemare NE, Akhurst RJ, Mourant RG (1993) DNA relatedness between Xenorhabdus spp. (Enterobacteriaceae), symbiotic bacteria of entomopathogenic nematodes, and a proposal to transfer Xenorhabdus luminescens to a new genus, Photorhabdus gen. nov. Int J Syst Bacteriol 43:249-255

Bowen DJ, Ensign JC (1998) Purification and characterization of a high-molecular weight insecticidal protein complex produced by the entomopathogenic bacterium Photorhabdus luminescens. Appl Environ Microbiol 64:3029-3035

Brar SK, Verma M, Tyagi RD, Valero JR (2006) Recent advances in downstream processing and formulations of Bacillus thuringiensis based biopesticides. Process Biochem 41(2):323-342

Burges HD, Jones KA (1998) Formulation of bacteria, viruses and protozoa to control insects. In: Burges HD (ed) Formulation of microbial pesticides: beneficial microorganisms, nematodes and seed treatments. Kluwer Academic Publishers, Dordrecht, pp 33-127

Bussaman P, Sermswan RW, Grewal PS (2006) Toxicity of the entomopathogenic bacteria Photorhabdus and Xenorhabdus to the mushroom mite (Luciaphorus sp.;Acari: Pygmephoridae). Biocontrol Sci Techn 16:245-256

Bussaman P, Sobanboa S, Grewal PS, Chandrapatya A (2009) Pathogenicity of additional strains of Photorhabdus and Xenorhabdus (Enterobacteriaceae) to the mushroom mite Luciaphorus perniciosus (Acari: Pygmephoridae). Appl Entomol Zool 44(2):293-299

Bussaman P, Sa-Uth C, Rattanasena P, Chandrapatya A (2012) Acaricidal activities of whole cell suspension, cell-free supernatant, and crude cell extract of Xenorhabdus stokiae against mushroom mite (Luciaphorus sp.). J Zhejiang Univ Sci B (Biomed Biotechnol) 13(4):261-266

Diehl T, Fehrmann H (1999) Wheat fusarioses: influence of infection date, tissue injury and aphids on leaf and ear attack. J Plant Dis Prot 96:393

Elad Y, Malathrakis NE, Dik AJ (1996) Biological control of Botrytis incited diseases and powdery mildews in greenhouse crops. Crop Prot 15:229-240

Ffrench-Constant RH, Dowling A, Waterfield NR (2007) Insecticidal toxins from Photorhabdus bacteria and their potential use in agriculture. Toxicon 49:436-451

Fillinger S, Chaveroche M, Van Dijck P, de Vries R, Ruijter G, Thevelein J, de Enfert C (2001) Trehalose is required for the acquisition of tolerance to a variety of stress in filamentous fungus Aspergillus nidulans. Microbiol 147:1851-1862

Forst S, Dowds B, Boemare N, Stackebrandt E (1997) Xenorhabdus and Photorhabdus spp.: bugs that kill bugs. Annu Rev Microbiol 51:47-72

Fravel DR, Connick WJ Jr, Lewis JA (1998) Formulation of microorganisms to control plant diseases. In: Burges HD (ed) Formulation of microbial pesticides: beneficial microorganisms, nematodes and seed treatments. Kluwer Academic Publishers, Dordrecht, pp 187-202

Gašić S, Tanović B (2013) Biopesticide formulations, possibility of application and future trends. Pestic Phytomed (Belgrade) 28(2):97-102

Gerritsen LJM, Georgieva J, Wiegers GL (2005) Oral toxicity of Photorhabdus toxins against Thrips species. J Invertebr Pathol 88(3):207-211

Herbert EE, Goodrich-Blair H (2007) Friend and foe: the two faces of Xenorhabdus nematophila. Nat Rev Microbiol 5:634-646

Herbert Tran EE, Andersen AW, Goodrich-Blair H (2009) CpxRA influences Xenorhabdus nematophila colonization initiation and outgrowth in Steinernema carpocapsae nematodes through regulation of the nil locus. Appl Environ Microbiol 75:4007-4014

Kandibane M, Kumar K, Adiroubane D (2010) Effect of Bacillus thuringiensis Berliner formulation against the rice leaf folder Cnaphalocrocis medinalis Guenee (Pyralidae: Lepidoptera). JBP 3(2):445-447 
Kaya HK, Stock SP (1997) Techniques in insect nematology. In: Lacey LA (ed) Manual of techniques in insect pathology. Academic Press, London, pp 281-324

Knowles A (2005) New developments in crop protection product formulation. Agrow Reports UK, pp 153-156

Lacey L (1997) Manual of Techniques in Insect Pathology. Biological Techniques Series. Academic Press, San Diego, pp 315-322

Lee JP, Lee SW, Kim CS, Son JH, Song JH, Lee KY (2006) Evaluation of formulations of Bacillus licheniformis for the biological control of tomato gray mold caused by Botrytis cinerea. Biol Control 37:329-337

Mahar AN, Munir M, Elawad S, Gowen SR, Hague NGM (2005) Pathogenicity of bacterium, Xenorhabdus nematophila isolated from entomopathogenic nematode (Steinernema carpocapsae) and its secretion against Galleria mellonella larvae. J Zhejiang Univ Sci B 6(6):457

Mahar AN, Jan ND, Mahar GM, Mahar AQ (2008) Control of insects with entomopathogenic bacterium Xenorhabdus nematophila and its toxic secretions. Int. J Agric Biol 10(1):52-56

Owuama Cl (2001) Entomopathogenic symbiotic bacteria, Xenorhabdus and Photorhabdus of nematodes. World J Microbiol Biotechnol 17(5):505-515

Sallam NA, Riad SN, Mohamed MS, El-eslam AS (2013) Formulations of Bacillus spp. and Pseudomonas fluorescens for biocontrol of cantaloupe root rot caused by Fusarium solani. J Plant Prot Res 53(3):295-300
Senthilraja G, Anand T, Durairaj C, Raguchander T, Samiyappan R (2010) Chitinbased bioformulation of Beauveria bassiana and Pseudomonas fluorescens for improved control of leafminer and collar rot in groundnut. Crop Prot 29(9):1003-1010

Shresth S, Kim Y (2010) Differential pathogenicity of two entomopathogenic bacteria, Photorhabdus temperate subsp. temperate and Xenorhabdus nematophila against the red flour beetle Tribolium castaneum. J Asia Pac Entomol 13(3):209-213

Sicard M, Brugirard-Ricaud K, Pages S, Lanois A, Boemare NE, Brehelin M, Givaudan A (2004) Stages of infection during the tripartite interaction between Xenorhabdus nematophila, its nematode vector, and insect hosts. Appl Environ Microbiol 70:6473-6480

Suprapta DN (2012) Potential of microbial antagonists as biocontrol agents against plant fungal pathogens. JISSAAS 18:1-8

Yang J, Zeng HM, Lin HF, Yang XF, Liu Z, Guo LH, Yuan JJ, Qiu DW (2012) An insecticidal protein from Xenorhabdus budapestensis that results in prophenoloxidase activation in the wax moth, Galleria mellonella. J Invertebr Pathol 110:60-67

\section{Submit your manuscript to a SpringerOpen ${ }^{\odot}$ journal and benefit from:}

- Convenient online submission

- Rigorous peer review

- Immediate publication on acceptance

- Open access: articles freely available online

- High visibility within the field

- Retaining the copyright to your article

Submit your next manuscript at $>$ springeropen.com 